\title{
Expression of Heat Shock Protein 70-1 in Peripheral Blood Mononuclear Cells of Jersey-Sahiwal Cross Breds during Thermal Stress
}

\author{
V. Manasa*, T. Venkata Sai Kumar and T. Prasada Rao \\ Department of Veterinary Biochemistry, SVVU \\ College of Veterinary Science, Proddatur, AP-516360, India \\ *Corresponding author
}

Keywords

HSP70-1 gene, Peripheral Blood Mononuclear Cells, Jersey- Sahiwal Cross Breds, Thermal Stress,

Article Info

Accepted:

18 May 2020 Available Online: 10 June 2020

\section{A B S T R A C T}

Heat Shock Protein 70 (HSP70) is one of the important molecular chaperon that can protect cells from thermal damage by involving in the maintenance of the intra cellular homeostasis primarily by controlling the process of protein folding. The indigenous breeds of cattle have been found to be more resistant to heat stress in comparison to the exotic breeds by way of expressing HSP70 as an adaptive response. Therefore, the present study was done to study the expression of HSP 70-1 in peripheral blood mononuclear cells (PBMCs) of Jersey- Sahiwal cross breds during thermal stress. Blood samples collected from the animals were used for the separation of PBMCs by using Histopaque 1077 and RBC lysis buffer. Total RNA was isolated from the separated PBMCs using Trizol reagent. The isolated total RNA was then reverse transcribed to cDNA that was used for amplification of HSP70-1 gene using specific pair of primers. The presence of 1926 base pair band in denaturing agarose indicated the amplification of HSP70-1 gene. To conclude, our results demonstrate that HSP701 gene is expressed in PBMCs of Jersey- Sahiwal cross breds and further characterization of this gene may help in elucidating its role in attributing thermo tolerance to the cross bred cattle.

\section{Introduction}

Thermal stress is defined as "a physiological condition when the core body temperature of a given species exceeds its range specified for normal activity, which results from a total heat load (internal production and environment) exceeding the capacity for heat dissipation and this prompts physiological and behavioral responses to reduce the strain" (Bernabucci et al., 2010). The variation in upper critical temperatures (UCT) depends upon age, breed, level of production and the degree of acclimatization (Shearer and Beede, 1990). The ability to adapt to environment is of great importance to all living things.

Cells respond to heat stress with the synthesis of heat shock proteins (HSPs) that can be transcribed and translated in high ambient temperatures. HSPs commonly referred to as molecular chaperones have been implicated in 
a wide variety of cellular processes, including protection of the proteome from stress, folding and transport of newly synthesized polypeptides, activation of proteolysis of misfolded proteins and the formation and dissociation of protein complexes. HSPs are the group of proteins which get expressed in response to many environmental conditions, including ultraviolet radiation, heavy metal ions, hypoxia and toxic agents. Heat shock genes are activated when cells are exposed to stress stimuli and form heat shock proteins (Christians et al., 2003).

Stressors that can induce HSP gene expression include physical and chemical insults such as radiation, including ultraviolet light and magnetic fields, compression, shearing and stretching, hypoxia, $\mathrm{pH}$ shift, nutrient deprivation, or exposure to reactive oxygen species, alcohols, or metals. Certain biological insults like fever, cold, infection, inflammation, diseases including cancer, cardiac diseases, and neuro degenerative disorders can also induce HSP gene expression. Broadly, cellular stress can also be triggered by treatments with anticancer drugs or antibiotics (Ciocca and Calderwood, 2005; Macario and Conwayde Macario, 2005; Garrido et al., 2006; Jego et al., 2010; Willis and Patterson, 2010; Macario et al., 2011).

The family of heat shock proteins consists of many proteins which are classified as HSP 110, HSP 100, HSP 90, HSP70, HSP 60, HSP 40, HSP 10, and other small HSP families (park et al., 2007; Gething., 1997). Among HSPs, heat shock protein 70 (HSP70) is an essential molecular chaperone of primary importance to all mammalian cells.

HSP70 gene family in bovines includes HSP70-1, HSP70-2, HSP70-3, and HSP70-4 gene. HSP70-1 is an intronless gene located on chromosome 23 of bovine (BTA 23) and has 1926 nucleotides. Heat Shock Protein-70
(HSP-70) is one of the most studied and inducible HSP families under stressful conditions which is often used as stress marker and adaptation in a variety of physiological systems (Beckham et al., 2004).

HSP70 is well reported to protect cells, tissues, and organs from stress (Kiang and Tsokos, 1998) by promoting the folding of nascent polypeptides and by correcting the misfolding of denatured proteins. Heat shockinduced- HSP70 expression has also a role in the anti-apoptotic pathway (Sreedhar and Csermely, 2004). Heat shock protein 70 (HSP 70) plays a vital role by bestowing cytoprotection against diverse kinds of stresses. Therefore, HSP 70 proteins are ubiquitous, the most abundant and temperature sensitive among all the HSPs.

Climate change and adapting to climate change by means of managing the heat stress will have a profound impact on household income and food security. The temperatures expected under climate change will precipitate heat stress and are found to cause decline in productivity. By 2020, heat stress was estimated to decrease the milk production from India's dairy cows by 0.73 million litres (Upadhyay et al., 2007).

Heat stress is measured against a temperature- humidity index (THI), a combined measure of temperature and humidity to denote thermal comfort (Berman, 2011). Thermal stress duration and magnitude can affect the concentrations of HSP-70 (Wang et al., 2003).The Bos indicus breeds such as Sahiwal and Gir are considered to be less susceptible to heat stress (Sirohi and Michaelowa, 2007; Upadhyay et al., 2007). Several studies have also confirmed genetic differences in thermo tolerance at the physiological and cellular levels in Bos Indicus and Bos Taurus (Lacetera et al., 2006; Farooq et al., 2010). 
Studies have also been conducted to find out the level of expression of these HSP genes and proteins in various tissues of bovines and other species, but the work on HSP70-1 gene expression in peripheral blood mononuclear cells (PBMCs) of cross bred cattle is limited (Parmar et al., 2015). Hence, the present study was initiated with the objective of studying the expression of HSP 70-1 in PBMNCs of Jersey- Sahiwal cross breds during thermal stress.

\section{Materials and Methods}

The present study was conducted at College of Veterinary Science, Proddatur, Sri Venkateswara Veterinary University. Six apparently healthy non lactating Jersey Sahiwal crossbreds were selected for the study. Blood samples were collected aseptically from these animals in $15 \mathrm{ml}$ centrifuge tubes using EDTA as an anticoagulant $(1 \mathrm{mg} / \mathrm{ml})$ by jugular vein puncture. The samples were collected during summer where in the temperature range was recorded as $38^{\circ} \mathrm{C}$ to $42^{\circ} \mathrm{C}$, THI $>72$. The collected blood samples were then immediately processed inorder to isolate the intact total RNA from the PBMCs.

\section{Isolation of peripheral blood mononuclear cells (PBMCs)}

PBMCs were isolated from whole blood using two methods- one by the use of Histopaque 1077 (Sigma) and the other by the use of RBC lysis buffer (routinely used for the isolation of DNA from the whole blood with slight modifications) (Sambrook and Russell, 2001). In the earlier method, $3 \mathrm{ml}$ of whole blood was carefully laid over $3 \mathrm{ml}$ of Histopaque 1077 taken in $15 \mathrm{ml}$ centrifuge tubes. Centrifuged at $1900 \mathrm{rpm}$ for $30 \mathrm{~min}$ at room temperature to collect the opaque interphase which is rich in PBMCs into a new centrifuge tube. Then $10 \mathrm{ml}$ of Diethyl pyrocarbonate -phosphate buffer saline (DEPC -PBS, pH 7.4) was added to the PBMCs and centrifuged at 1600 $\mathrm{rpm}$ for $10 \mathrm{~min}$ at room temperature. The pellet was again washed with $5 \mathrm{ml}$ of DEPC PBS and centrifuged at $1600 \mathrm{rpm}$ for $10 \mathrm{~min}$ at room temperature. The supernatant was removed and the contents were transferred to a new $2 \mathrm{ml}$ eppendorf tube to which $0.5 \mathrm{ml}$ of DEPC -PBS was added.

The remaining $12 \mathrm{ml}$ of whole blood was centrifuged at $2000 \mathrm{rpm}$ for $15 \mathrm{~min}$ at room temperature. $300 \mu 1$ of buffy coat was separated carefully and added to $2 \mathrm{ml}$ eppendorf tube. To this, $900 \mu \mathrm{l}$ of RBC lysis buffer was added and incubated at room temperature for $10 \mathrm{~min}$. Then centrifuged at $12000 \mathrm{rpm}$ for $1 \mathrm{~min}$ at room temperature. The above step was repeated 3-4 times till a white WBC pellet was obtained. The final WBC pellet was suspended in $0.5 \mathrm{ml}$ of DEPC -PBS.

\section{Extraction of total cellular RNA from PBMCs}

The PBMCs obtained by using Histopaque 1077 as well as RBC lysis buffer, and resuspended in $0.5 \mathrm{ml}$ of DEPC -PBS, were used to extract the total cellular RNA using Trizol reagent. $1 \mathrm{ml}$ of trizol and $200 \mu \mathrm{l}$ of chloroform were added to the DEPC -PBS resuspended PBMCs. Mixed well and incubated for $3 \mathrm{~min}$ at room temperature.

Centrifuged at $14,000 \mathrm{rpm}$ for $15 \mathrm{~min}$ at $4^{\circ} \mathrm{C}$. The upper aqueous phase resulted in the phase seperation was then transferred to a new eppendorf tube and $0.5 \mathrm{ml}$ of isopropanol was added, vortexed and placed in $-20^{\circ} \mathrm{C}$ overnight, followed by centrifugation at $14,000 \mathrm{rpm}$ for $15 \mathrm{~min}$ at $4^{\circ} \mathrm{C}$. The obtained pellet was rinsed with ice-cold $70 \%$ ethanol and centrifuged at 7,500 rpm for $8 \mathrm{~min}$ at $4^{\circ} \mathrm{C}$. The isolated RNA was then reconstituted in nuclease free water (Himedia). 


\section{Ascertaining the purity and concentration} of RNA

The purity and concentration of total RNA isolated by both the methods was verified by measuring the optical density (OD) absorption ratio OD 260: OD $280 \mathrm{~nm}$ using Nanodrop spectrophotometer (Thermo scientific).

The quality and integrity of total RNA was checked using denaturing agarose gel (1.5\%) electrophoresis and visualized under UV light with the help of Chemi documentation system from syngene, Biocon, USA. The isolated total RNA samples whose absorption ratio OD 260: OD $280 \mathrm{~nm}$ ranging between 1.8 and 2.0 were used for the cDNA synthesis.

\section{Statistical analysis}

Students paired t test (Nemeth et al., 2004) was used to calculate and compare the difference in the concentration and purity of total RNA isolated from PBMCs by using Histopaque 1077 and RBC lysis buffer (in terms of $p$ value).

\section{RNA reverse transcription}

Isolated total RNA was reverse transcribed using Hi-cDNA synthesis kit from Himedia, India. Template RNA, $5 \mu \mathrm{l}$; oligo dT, $1 \mu \mathrm{l}$ and nuclease free water, $4 \mu \mathrm{l}$ were added to a PCR tube, incubated at $65^{\circ} \mathrm{C}$ for $5 \mathrm{~min}$ in a thermal cycler and cooled immediately on ice in order to use this a template for synthesis of complementary DNA.

A reaction mixture $(20 \mu \mathrm{l})$ was then prepared in a PCR tube using $4 \mu \mathrm{g}$ of total RNA (adjusted to $10 \mu \mathrm{l}$ ), $4 \mu \mathrm{l}$ of RT buffer for MMuLV, $2 \mu 1$ of 10X solution for MMuLV, 1 $\mu 1$ of M-MuLV reverse transcriptase (RNaseH-), $2 \mu \mathrm{l}$ of $10 \mathrm{mM}$ dNTP mix and $1 \mu \mathrm{l}$ of nuclease free water. The mixture was then short spinned and incubated at $42^{\circ} \mathrm{c}$ for 90 $\min$. The reaction was stopped by heating the mixture at $85^{\circ} \mathrm{C}$ for $5 \mathrm{~min}$ and chilled on ice. The integrity of the cDNA was checked using $\beta$-actin primers as housekeeping (control) gene (Puech et al., 2015).

In order to amplify the full length Open Reading Frame (ORF) of HSP70-1 gene sequence, a specific primer pair was used based on the HSP70-1 m RNA sequence of cattle (Gade et al., 2010). The specific sets of primers used in the experiment were synthesized from Eurofins Genomics India Pvt. Ltd., Bangalore (Table 1).

The master mix for the reaction contained 50 picomoles of each forward and reverse primers, $5 \mu 1$ of template cDNA, $5 \mu 1$ of $10 \mathrm{X}$ green Taq green buffer, $1 \mu \mathrm{l}$ of $10 \mathrm{mM} \mathrm{d}$ NTP mix and 1.25 units of green Taq green DNA polymerase. The final volume of the reaction mix was made to $50 \mu \mathrm{l}$ with nuclease free water. Amplification conditions were as follows: an initial denaturation of $93^{\circ} \mathrm{C}$ for 3 minutes; 30 cycles of $93^{\circ} \mathrm{C}$ for $15 \mathrm{sec}, 51^{\circ} \mathrm{C}$ for $30 \mathrm{sec}$ and $68^{\circ} \mathrm{C}$ for $1.54 \mathrm{~min}$ and a final extension step at $72^{\circ} \mathrm{C}$ for $10 \mathrm{~min}$.

\section{Results and Discussion}

\section{RNA extraction}

The use of Histopaque 1077 (Sigma) and the use of RBC lysis buffer for the separation of PBMCs had no significant difference/influence ( $\mathrm{p} \geq 0.1$ ) on the purity and concentration of total RNA extracted from the cells. The details are given in table 2 . Further, the integrity of the total RNA isolated from PBMCs (using both the methods) was further confirmed by using denaturing agarose gel (1.5\%) electrophoresis. Two intact bands of $28 \mathrm{~S}$ and 18S r RNA were obtained which confirmed the intactness of the total RNA isolated (Fig. $1)$. 
Table.1 Primer sequences for HSP 70-1 and $\beta$-actin genes used in RT-PCR

\begin{tabular}{|c|c|c|c|}
\hline \multicolumn{2}{|c|}{ Name of the gene } & \multirow{2}{*}{$\begin{array}{c}\text { Sequence }\left(\mathbf{5}^{\prime} \rightarrow \mathbf{3}^{\prime}\right) \\
\text { ATGGCGAAAAACATGGCTATC }\end{array}$} & $\begin{array}{c}\text { Expected } \\
\text { product size }\end{array}$ \\
\hline \multirow[t]{2}{*}{ HSP 70-1 } & $\mathrm{F}$ & & \multirow{2}{*}{1926 bp } \\
\hline & $\mathrm{R}$ & СТААТССАССТССТСААТ & \\
\hline \multirow[t]{2}{*}{$\beta$ actin } & $\mathrm{F}$ & TGGGCATGGAATCCTG & \multirow{2}{*}{194 bp } \\
\hline & $\mathrm{R}$ & GGCGCGATGATCTTGAT & \\
\hline
\end{tabular}

Table. 2 Mean $( \pm$ SE) values of the concentration of total cellular RNA and absorption ratio OD 260nm : OD $280 \mathrm{~nm}$ of the total RNA isolated from PBMCs of Jersey- Sahiwal cross breds during thermal stress

\begin{tabular}{|l|c|c|}
\hline \multicolumn{1}{|c|}{ Type of the Method } & $\begin{array}{c}\text { Concentration of total } \\
\text { cellular RNA } \\
(\mathbf{n g} / \boldsymbol{\mu l})\end{array}$ & $\begin{array}{c}\text { Absorption ratio } \\
\text { OD 260nm : OD 280 } \mathbf{~ n m}\end{array}$ \\
\hline $\begin{array}{l}\text { Using Histopaque 1077 for } \\
\text { the separation of PBMCs }\end{array}$ & $313.8 \pm 18.3$ & $1.8 \pm 0.03$ \\
\hline $\begin{array}{l}\text { Using RBC lysis buffer for } \\
\text { the separation of PBMCs }\end{array}$ & $297.2 \pm 22.9$ & $1.8 \pm 0.2$ \\
\hline
\end{tabular}

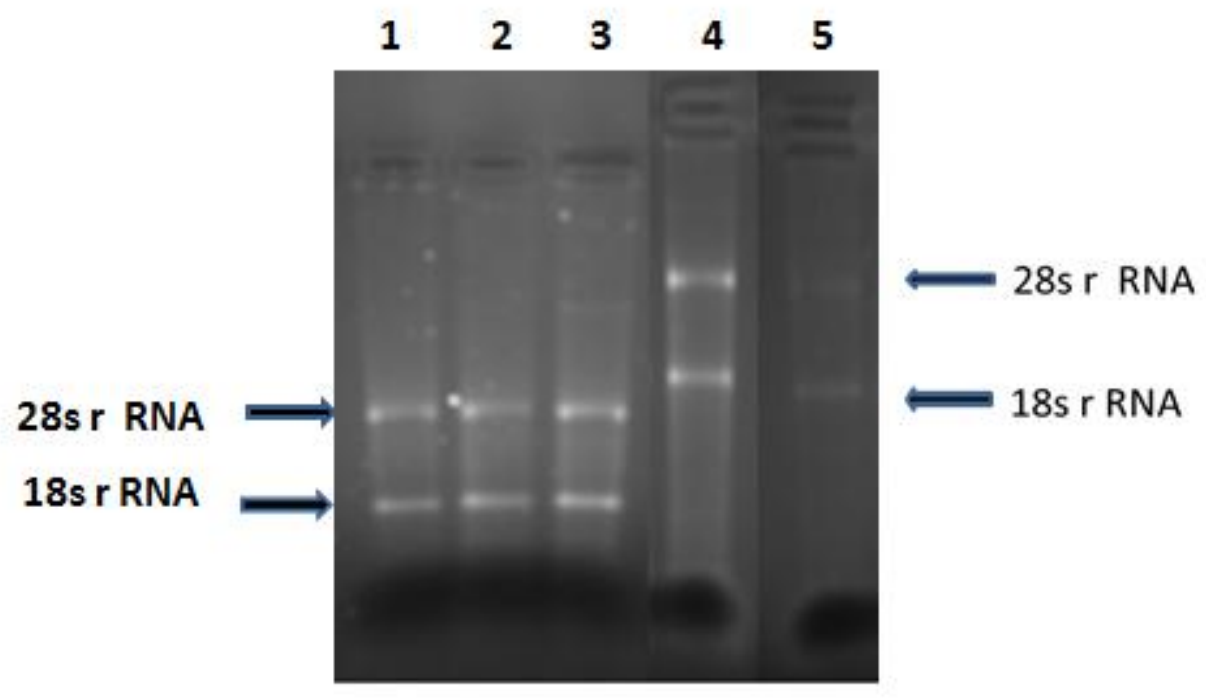

Fig.1 1\% formaldehyde agarose gel electrophoresis of RNA isolated from PBMCs of JerseySahiwal cross breds during thermal stress- Lanes 1, 2 and 3 (Histopaque 1077) ;

Lanes 4 \& 5 ( RBC lysis buffer) 


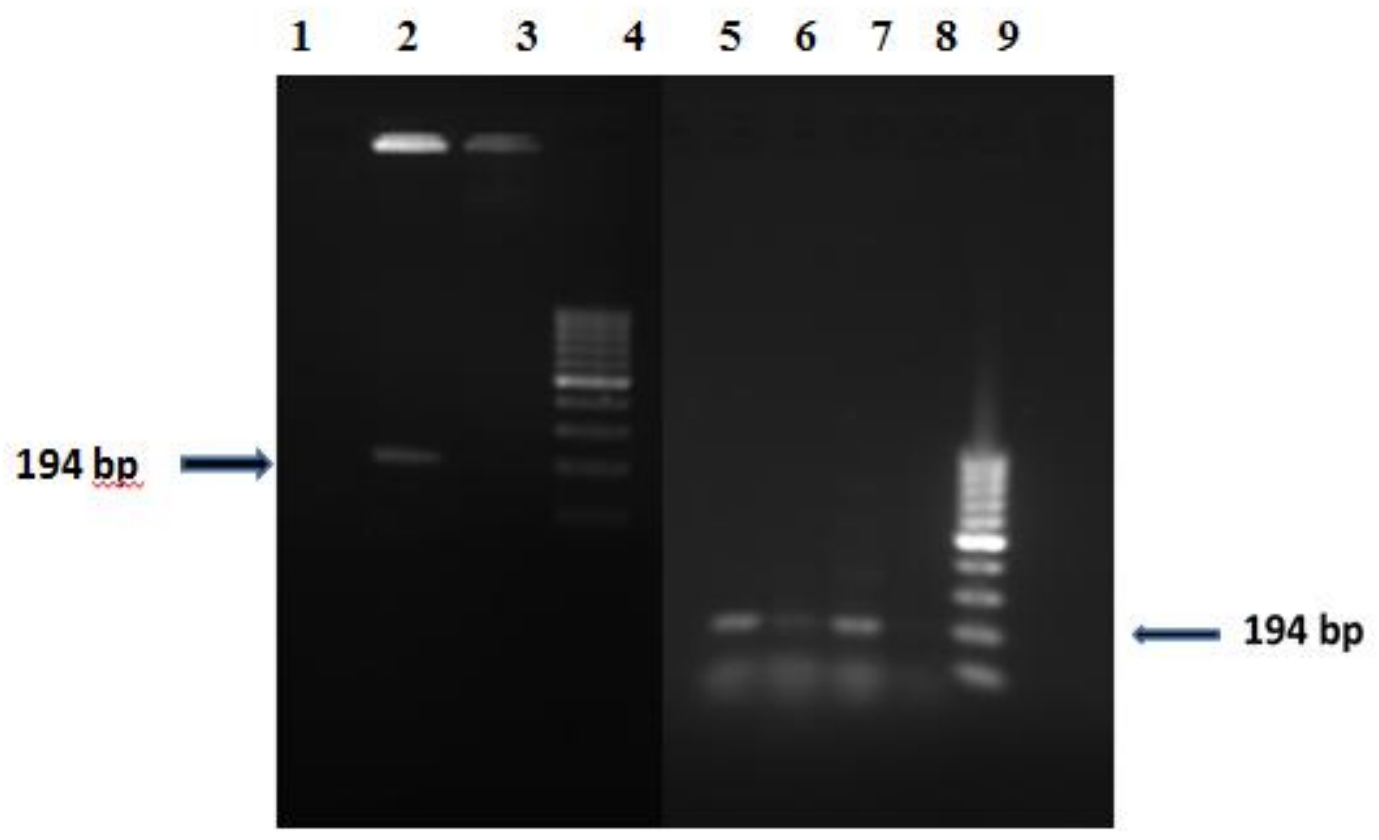

Fig.2 $\beta$ - actin (house keeping gene) amplified gene fragment of $194 \mathrm{bp}$ Lane 1 \& 8: Negative control, Lanes 2, 5, 6 \& 7: 194 bp amplified product of $\beta$ - actin gene, Lanes 4 \& 9: 100bp DNA ladder

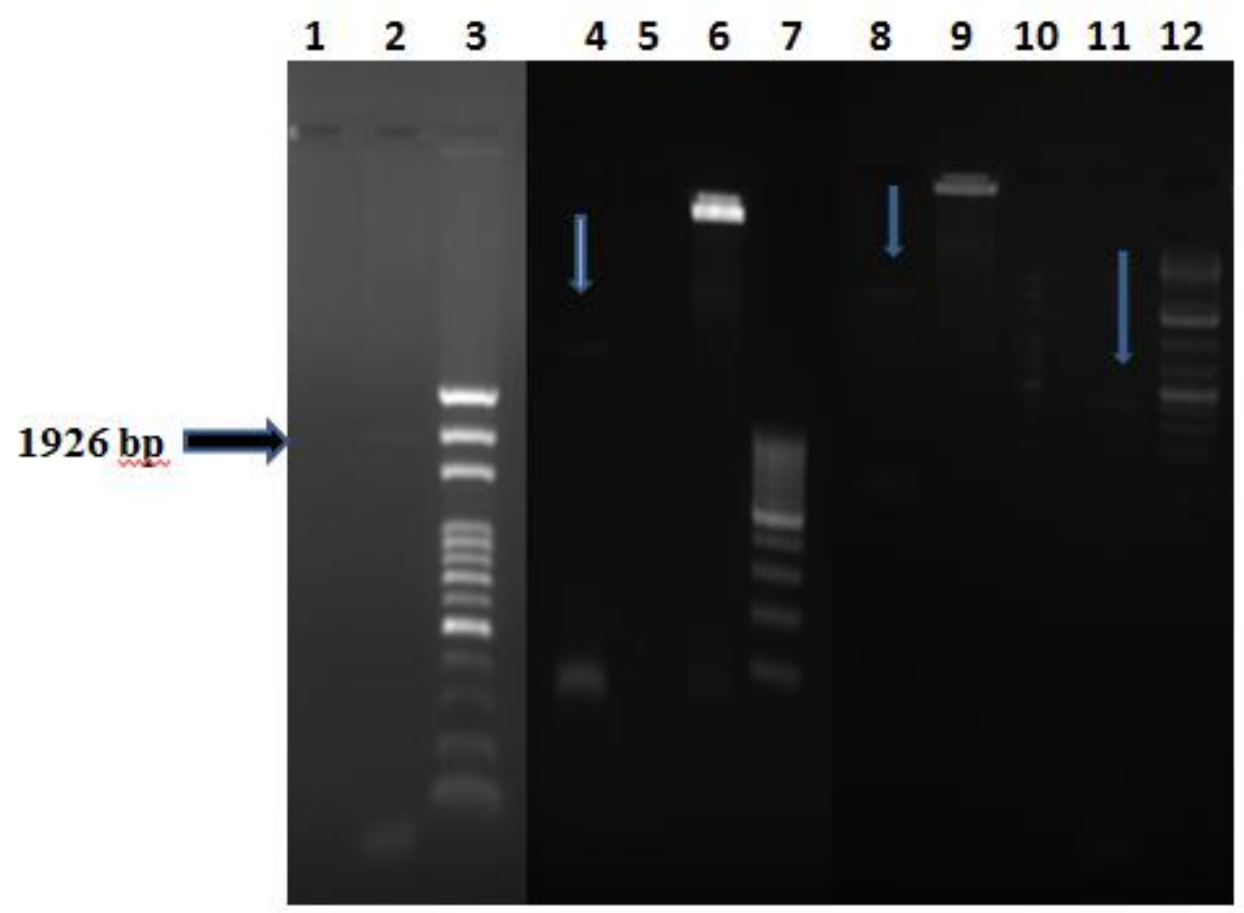

Fig.3 HSP 70-1 amplified gene product of 1926 bp by RT-PCR

Lanes 1 \& 5: Negative control, Lanes 2, 4, 8 \& 11: 1926bp RT-PCR amplified HSP 70-1 gene product, Lane 7: 100bp DNA ladder, Lane $3 \&$ 10: 100 bp DNA ladder with extra 3 bands of 1500, 2000 and 3000 bp respectively, Lane 12: $1 \mathrm{~kb}$ plus DNA ladder 


\section{Complementary DNA synthesis}

First strand of cDNA was synthesized from all the samples and its integrity was checked by PCR with the house keeping gene, $\beta$-actin gene primers which amplified 194 bp specific gene fragment (Fig. 2). PCR amplification using the set of primers for the amplification of full length HSP70-1 gene resulted in the production of $1926 \mathrm{bp}$ specific PCR product that was amplified from the reverse transcribed cDNA (Fig. 3).

Adaptation to thermal stress involves the coordination of respiratory, circulatory, excretory, nervous and endocrine systems of the body. However, the adaptability response to heat stress varies between Bos indicus, Bos Taurus and between the cross bred cows (Khan et al., 2018). Heat shock protein is an important biomarker produced as cellular and tissue defense mechanism whose expression gets markedly increased during heat stress (Lindquist., 1986). Among the various HSPs, HSP70 family of proteins are found to be having potential role in attributing thermotolerance to cows. HSP70 has also been found to be an ideal candidate genetic marker for selection of animals with better climate resilience, immune response and superior performance. The present in vivo study elucidated that there is expression of HSP70-1 in PBMNCs of Jersey- Sahiwal cross breds during thermal stress. And, genetic selection of animals based on their thermo tolerance can become one of the possible moves towards reducing the impact of heat stress on cattle productivity by studying the expression of HSPs in PBMCs.

\section{Acknowledgement}

The authors are thankful to Sri Venkateswara Veterinary University, India for providing financial assistance to carry out this research work.

\section{References}

Beckham, J.T., M.A. Mackanos, C. Crooke, T.Takahashl, C.O.Connell- Rodwell, C.H.Contag and E.D. Jansen. 2004. Assessment of Cellular Response to Thermal Laser Injury Through Bioluminescence Imaging of Heat Shock Protein 70 Photochem.Photobiol. 79(1): 76-85. https://doi.org/10.1562/00318655

Berman. A., 2011. Invited review: are adaptations present to support dairy cattle productivity in warm climates? Journal of Dairy Science 94, 21472158.

Bernabucci, U., N. Lacetera, L.H. Baumgard, R.P. Rhoads, B. Ronchi and A.Nardone. 2010. Metabolic and hormonal acclimation to heat stress in domesticated ruminants. Animal. 4 (07): 1167-1183. https://doi.org/10.1017/ S175173111000090X

Christians, E. S., Q. Zhou, J. Renard, and I. J. Benjamin. 2003. "Heat shock proteins in mammalian development," Seminars in Cell and Developmental Biology, vol. 14, no. 5, pp. 283-290.

Ciocca, D.R., and S. K. Calderwood. 2005. Heat shock proteins in cancer: diagnostic, prognostic, predictive, and treatment implications. Cell Stress Chaperones. 10, 86-103.

Farooq, U., A. Qayyum, H. Samad and H. Chaudhry. 2010. Physiological responses of cattle to heat stress. 30th Pakistan Congress of Zoology (International).

Gade. N., R.K. Mahapatra, A. Sonawane, V.K. Singh, R. Doreswamy and M. Saini. 2010. Molecular Characterization of Heat Shock Protein 70-1 Gene of Goat (Capra hircus ) Molecular Biology International Volume 2010, Article ID 108429, 7. doi:10.4061/2010/108429.

Garrido, C., M. Brunet, C. Didelot, Y. 
Zermati, E. Schmitt and G. Kroemer. 2006. Heat

Gething, M.J, ed. 1997. Guidebook to Molecular Chaperones and ProteinFolding Catalysts. Oxford, UK: Oxford Univ. Press

Jego, G., A. Hazoume, R. Seigneuric and C. Garrido. 2010. Targeting heat shock proteins in cancer. Cancer Lett. 332(2):275- 285. doi:10.1016/j.canlet.2010.10.014

Khan. I., M.S. Quershi, S. Akhtar, I. Ali and G. Ullah . 2018. Crossbred cows respond differently from holstein frisian and bos indicus to heat stress under various climatic conditions. Sarhad Journal of Agriculture, 34(2): 301-310. 10.17582/journal.sja/2018/34.2.301.310

Kiang J. G., and G. C. Tsokos. 1998. "Heat shock protein $70 \mathrm{kDa}$ : molecular biology, biochemistry, and physiology," Pharmacology and Therapeutics, vol. 80, no. 2, pp. 183-201.

Lacetera, N., U. Bernabucci, D. Scalia, L. Basirico, P. Morera and A. Nardone. 2006. Heat stress elicits different responses in peripheral blood mononuclear cells from Brown Swiss and Holstein cows. J. Dairy Sci. 89(12): 4606- 4612. https://doi.org/10.3168/ jds.S0022-0302(06)72510-3

Lindquist S., 1986. The heat-shock response. Annu Rev Biochem. 55:11511191. doi:10.1146/annurev.bi.55. 070186.005443

Macario, A.J., and Macario. E. Conwayde. 2005. Sick chaperones, cellular stress, and disease. N. Engl. J. Med. 353, 1489-1501.

Macario, A.J., F. Cappello, G. Zummo, G and Macario, E Conwayde. 2011. Chaperonopathies of senescence and the scrambling of interactions between the chaperoning and the immune systems. Ann.N.Y. Acad.Sci. 1197, 85-93.

Nemeth, E., S. Rivera , V. Gabayan, C.
Keller, S. Taudorf S, B.K. Pedersen and T. Ganz 2004. IL-6 mediates hypoferremia of inflammation by inducing the synthesis of the iron regulatory hormone hepcidin, The Journal of Clinical Investigation, 113: 1251

Park, H., I.Y. Ahn and H.E. Lee. 2007. Expression of Hsp70 in the thermally stressed Antarctic clam Laternula elliptica. Cell Stress and Chaperons. 12, 275-282

Parmar, M.S., A.K. Madan, S.K. Rastogi and R. Huozha. 2015. Expression of heat shock protein70-1 gene in bovine peripheral blood mononuclear cells. Indian Journal of Animal Research(49):325-327

Puech, C., L. Dedieu, I. Chantal and R. Valerie. 2015. Design and evaluation of a unique SYBR Green real-time RTPCR assay for quantification of five major cytokines in cattle, sheep and goats. BMC Vet Res 11, 65 . https://doi.org/10.1186/s12917-0150382-0

Sambrook J., and D.W. Russell. 2001. Molecular cloning: a laboratory manual, Vol. 1, 3rd edition. Cold Spring Harbor, NY: Cold Spring Harbor Laboratory Press. p 6.23-6.27

Shearer, J. K., and D. K. Beede. 1990. Thermoregulation and physiological responses of dairy cattle in hot weather. Agri-Practice. 11:5-17.

Shock proteins 27 and 70: anti-apoptotic proteins with tumorigenic properties. Cell Cycle 5, 2592-2601.

Sirohi .S., and A. Michaelowa. 2007. Sufferer and cause: Indian livestock and climate change. Climatic Change 85, 285-298

Sreedhar A. S. and P. Csermely. 2004. "Heat shock proteins in the regulation of apoptosis: new strategies in tumor therapy- a comprehensive review," Pharmacology and Therapeutics, vol. 
101, no. 3, pp. 227-257.

Upadhyay R.C, M. Mohini, V.K. Kansal, S.V.

Singh, A. Ashutosh, S.K. Sirohi and S.

Kumar. 2007. Final report of the

Network Project on Climate Change.

National Dairy Research Institute,

Karnal, India.

Wang, S., K.R. Diller and S.J. Aggarwal.
2003. Kinetics study of endogenous heat shock protein 70 expression. J. Biomechanic. Engineer. 125(6): 794797. https://doi.org/10.1115/1.1632522

Willis,M.S., and C. Patterson. 2010. Hold me tight: role of the heat shock protein family of chaperones in cardiac disease. Circulation 122, 1740-1751.

\section{How to cite this article:}

Manasa. V., T. Venkata Sai Kumar and Prasada Rao. T. 2020. Expression of Heat Shock Protein 70-1 in Peripheral Blood Mononuclear Cells of Jersey- Sahiwal Cross Breds during Thermal Stress. Int.J.Curr.Microbiol.App.Sci. 9(06): 1271-1279.

doi: https://doi.org/10.20546/ijcmas.2020.906.157 